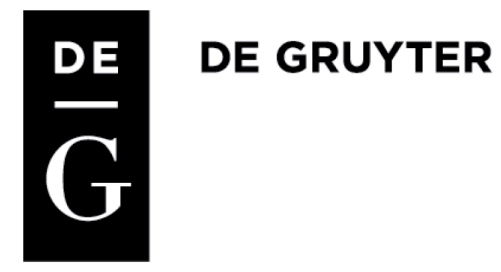

\title{
"IN ORDER TO ADAPT THE CONSUMPTION...". THE CREATION OF A RATIONING SYSTEM FOR PETROL IN THE POLISH PEOPLE'S REPUBLIC IN THE 1980s
}

In post-war Poland, rationing was introduced on three occasions: right after the war in 1945, then in 1951, and at the turn of the 1980s. In 1976, rationing cards for sugar were introduced, in 1981 for meat, fats, cereal products, cleaning products and many other goods. Fuels were the last product added to this list. This article describes the process of introducing a rationing system for petrol in the Polish People's Republic. Though the supply system crashed as early as 1981, it took several years to organize a rationing system for petrol. Its evolution did not end until 1984. This delay was caused by the long discussions on how the system should be built. This forced the authorities to introduce a whole range of temporary solutions which limited the demand in the short run, but had no soothing effect whatsoever on the society. To the contrary - the chaos they created intensified negative tendencies (such as speculation), led to market insecurity, and increased mistrust of state regulations.

Key words: Polish People's Republic, rationing system, controlled distribution, petrol

doi:10.1515/sho-2017-0006

\section{INTRODUCTION}

Regardless of the economic system functioning in a given state, authorities tried to refrain from directly intervening in the exchange of goods even in an economy fully controlled by the state. However, this was not possible in times of great deficits, especially when these posed a fundamental threat to the state's functioning. In such cases, the authorities resorted to the mechanism of controlled distribution of popular products.

This involved limiting the possibility of purchasing or consuming both production and consumer goods. In the case of consumer goods, distribution was controlled when the demand significantly exceeded the sup- 
ply. This could be caused by extraordinary circumstances, such as natural disasters, crop failure, war, or deep economic crisis. The aim of controlled distribution was to alleviate the effects of insufficient supply of some products, caused by factors that were difficult to neutralize and/or limited imports [Szlichciński K., 2002: 92]. The first products to be controlled were always the most popular ones, such as bread, sugar, flour, meat, fats, and fuels. Naturally, the system could also include any other products, for example non-alimentary consumer goods.

Controlled distribution could be introduced temporarily (spontaneously) by a supplier or seller, or by administrative bodies within an organized rationing system [Kornai J., 1985: 550-551]. Spontaneous control meant that the product in short supply was sold to those waiting for its delivery in limited amounts. The size of an allotment was determined individually, depending on the situation. The decision concerning the amount to be sold could be made by the seller (sometimes on demand of the buyers) or by their superior.

The system of spontaneous control could not be applied in the long term due to its imperfections: it was difficult to introduce a single set of rules applicable to large areas of the country, it was also impossible to prevent customers from buying multiple allotments of the deficit goods (in the same outlet or in a different one). An efficient and complete mechanism of controlling the introduced solutions simply could not exist. In fact, the spontaneous control mechanism was based entirely on trust towards the sellers. Finally (and this aspect is probably the most important), the system was one-dimensional, and did not allow for special treatment of specific groups of buyers. That is why it was necessary to come up with a more formal system of controlled distribution - namely, rationing. This system allowed for specifying and controlling the size of rations, as well as for subsidizing consumption and adjusting prices to the society's purchasing power, and to some extent also for fighting abuses, in particular speculation [Mała Encyklopedia Ekonomiczna (Short Economic Encyclopedia), 1974: 682].

Rationing was an administrative system of sale organization imposed on the set of market relations. It constituted a direct intervention of the state into the rules of distribution. Usually, it was applied when other methods of solving problems with market imbalances failed or were impossible to implement [AAN, IRWiK (Archive of New Files, Institute of Internal Market), 318: 47]. In theory, the role of the state was to create a system whose main objective was to provide fair access to the rationed goods to everyone. The "fair" level was determined by the state based on 
a number of criteria including economic, medical, political, and military factors. It was reflected by the size of rations assigned to specific groups of recipients. Having the right document was the second condition (beside having the required amount of money) to purchase the goods considered to be in short supply. Rationing was an administrative tool meant to solve the problem of distribution - temporarily, because the principles of rationing were in contrast to many fundamental economic rules, such as freedom to spend financial means or the principle of supply and demand - also present to some extent in a state-controlled economy

In post-war Poland, rationing was introduced on three occasions: right after the war in 1945, then in 1951, and at the turn of the 1980s. In 1976, rationing cards for sugar were introduced, in 1981 - for meat, fats, cereal products, cleaning products and many other goods. Fuels were the last product added to this list.

The analysis of the archives of central institutions can lead one to formulate a thesis that the authorities of the Polish People's Republic were not ready to introduce the rationing system for petrol. This was quite surprising, as such a system should have been developed ahead of time. The authorities were forced to introduce a whole range of temporary solutions which limited the demand in the short-run, but had no soothing effect whatsoever on the society. To the contrary - the chaos they created intensified negative tendencies (such as speculation), led to market insecurity, and increased mistrust of state regulations.

\section{BEFORE THE CRISIS}

As a result of the failure to provide full supply of petrol to meet the demand, in July 1981, petrol sale disruptions began, evidenced by the constantly growing queues at petrol stations [AAN, URM (Archive of New Files, Council of Ministers Office), 32/5, p. 14] - this is how the management of the CPN (Head Office for Petroleum Products) company warned the government in the autumn of 1981. Indeed, 15\% less 78-octane ("blue") petrol was supplied to the market than in the previous year, though there was nearly 10\% more 94-octane ("yellow") petrol (which, however, was not enough either) [Suchecki B., 1981: 14]. This situation was made even worse by the overall poor condition of the Polish trade - queues, empty shelves in shops, rationing cards. All that created panic that also spread 
to petrol stations. In 1981, Poles stood in enormous queues in front of petrol pumps.

The situation in the fuel market had been worsening since the late 1970s, due to the fact that the Polish economy was very energy-intensive, and to the rapidly increasing number of private cars on the roads. In 1975, there was one private car per 35 Poles; in 1978 - 1 per 21, and in 1981 1 per 15 . The state budget could not handle the growing demand for fuels [AAN, GIGE (Archive of New Files, General Inspectorate of Energy Management), 7/20: p. 76].

Controlled consumption of liquid fuels was introduced for the first time in 1978, and included six national bodies that bought the largest quantities of fuels [AAN, GIGE 7/23: p. 1-5]. Exceeding the limit was punishable with a fine in the amount of triple the value of the excessive consumption (based on retail prices). This system did not work at all, and the fines were not considered too oppressive. Therefore, in April 1979 [AAN, GIGE 7/23: p. 22-24; AAN, GIGE 7/23: p. 38-41], specific rations were introduced for the national bodies, as well as the corresponding "vouchers" (for wholesale deliveries to internal, or "garaged" petrol stations) or petrol tickets (for purchases in public petrol stations). This system affected more people - it included 20 bodies and some institutions, accounting for around $80 \%$ of the national consumption by the nationalized sector [AAN, GIGE $7 / 19$, p. 75]. The introduction of the system was also used as an opportunity to slightly lower the existing rations [AAN, GIGE 7/23, p. 26], which worked for the next few months ${ }^{1}$ [AAN, GIGE 1/2, p. 6-7]. On May 1, 1980, the rationing system was extended to cover the entire nationalized sector [AAN, GIGE 7/23, ff. 45-52; AAN, GIGE 7/23, p. 93-105]. Nationalized economic entities, as well as political and social organizations, could buy petrol and diesel fuel only if they had petrol tickets (in public petrol stations at retail prices) or vouchers (directly in CPN for the needs of own garaged stations). Limits for those purchases were determined by the central office every three months. An appeals procedure was also provided for those entities which were dissatisfied with their ration, as well as a system of "pre-issuing" authorizations to buy petrol [AAN, GIGE 7/2, p. 2-15]. Gradually, the limitations began to bring the desired effect. Until 1979, deliveries for the nationalized sector grew, up to the amount of 2,181,000 tons of fuels annually. Since 1980, a clear decrease in deliveries was observed to 1,771,000 tons in 1981 [AAN, GIGE 7/19, p. 75-76].

${ }^{1}$ Political parties were excluded from the rationing system, as well as the units of the Sejm Chancellery, State Council and the Council of Ministers Office. 
The situation became even more dynamic in 1981. Processing of crude oil in Poland decreased from 17.1 million tons in 1979 to 13.5 million tons (with available production capabilities enabling the processing of 18 million tons) ${ }^{2}$ [AAN, URM1.4/35, f. 9; AAN, URM 1.4/35, p. 42]. Furthermore, supplies from abroad were even smaller due to deductions of supplies that the state had accepted in advance in 1980. Fuel stocks for trade were empty. It became obvious that limitations must go beyond the nationalized sector to include individual customers. At that point, the authorities considered four possible scenarios:

- radical increase of petrol prices for individual customers to achieve market balance (it was feared that this would result with a large and uncontrolled "leak" of petrol intended from the nationalized sector)

- partial or complete ban on car traffic (which could be met with a very negative public reaction and, at the same time, overburden the public transport)

- introduction of rationing in combination with market prices (the socalled mixed system)

- introduction of rationing for everyone [AAN, GIGE 7/36, p. 1-4].

The last two solutions seemed most reasonable. The draft of a rationing system for petrol stipulated that the decisive factor when determining the size of a ration was "engine capacity and the type of driver". Calculations were made based on the average monthly mileage $-500 \mathrm{~km}$ per passenger car or single-track vehicle, and $1500 \mathrm{~km}$ per truck. For those whose used cars for professional purposes, higher rations were provided. Possibility to control rations on a regular basis was considered an advantage of the system, as it would directly lead to savings. Disadvantages included a long (several-month) period of implementation, costly maintenance and even more red tape [AAN, GIGE 7/36, p. 6-7].

It was impossible to ignore that the authorities did all they could to avoid the introduction of petrol cards. During the development of the above-mentioned analysis, it was pointed out that this type of solution had never succeeded in any other country - which was not true. Petrol distribution was controlled, for instance, during the Second World War in the USA. It is true, though, that the concept of rationing, planned in the USA in the years of petrol shock, was not implemented. In Poland, what

2 This meant it was possible to produce 4.25 million tons of diesel fuel and 2.25 tons of petrol. Out of that amount, 1.3 million tons of petrol were for sale. Assuming an average annual car mileage of $9,000 \mathrm{~km}$, petrol supply at that level could satisfy $50 \%$ of the demand. 
was feared the most was increase in speculation and "leaks" of the petrol intended for the nationalized sector.

Among the presented ideas suitable for fast implementation, the most radical one involved limiting the traffic of privately-owned cars. And indeed, in 1981, authorities considered a concept of "alternate traffic" for passenger cars (according to whether the registration plate number ended in an odd or even number) ${ }^{3}$ [AAN, URM 135/11, p. 27-28; AAN, URM 135/26, p. 21-22], which would be in force except on Fridays, Saturdays, and holidays; or even a complete ban of such traffic. Medical doctors, representatives of field administration, postmen, some technical workers, the disabled, taxi drivers and people who used cars for professional purposes were to be provided with special permissions (in the case of a complete ban, the latter group was to be allowed to use cars only on working says) [AAN, GIGE 7/36, p. 9-10]. However, these limitations were in the end considered impossible to enforce.

The appropriate decisions regulating petrol sale in the time of insufficient supply were not made quickly. Finally, in November 1981, the authorities decided to raise fuel prices., which, however, did not bring any tangible results.

At the same time, from August 1981, the authorities worked on the rules of widespread fuel rationing. This work was conducted with certain anxiety, as some were strongly against this solution. One of the main concerns was that petrol production figures for 1982 were still unknown. It was thought that only a level similar to the one from 1981 could ensure the system's stability [AAN, URM 135/34, p. 26]. For a very long time, nobody wanted to make such a promise [AAN, URM 135/35, p. 100]. It was pointed out that the introduction of cards (in the mixed system) would lead to the simultaneous functioning of three prices: the one on the card, the commercial price, and the intermediary price comprising the rationed price plus the cost of acquiring the card in the black market [AAN, URM 135/37, p. 51].

As already mentioned, discussions dragged on for months. However, constant petrol shortages led to the emergence of spontaneous and sometimes uncontrolled forms of petrol rationing. The solutions were imple-

${ }^{3}$ It was pointed out that in the time of fuel crises, such a system was used in Western Europe - in West Germany, France and Austria. Also, Yugoslavia tried to limit petrol consumption this way, but the idea was quickly abandoned, as the law was impossible to enforce. 
mented on a local and regional level, with noticeable mutual inspirations. For example, petrol stations were divided into sections for the privileged customers and the rest; filling fuel cans was prohibited; the size of a single transaction was limited (usually to 10 liters for cars up to $950 \mathrm{~cm}^{3}$ engine capacity and to 20 liters for larger cars); and number-plate based restrictions were applied (the last digit of the registration number determined the right to buy petrol on even- or odd-numbered days) [IPN Bu 1550/195, p. 30; AAN, URM 32/5, p. 14-15; Rozsadku! (Think!), 1981: 2]. In the diesel fuel market, the situation was slightly different - in 1981, people living in the countryside started to stock up on diesel fuel on a mass scale. As a result, in some regions customers were only allowed to buy 200 liters in a single transaction [AAN, URM 135/35, p. 106]. This way, the demand could be satisfied on a day-to-day basis. These solutions were temporary and were meant to maintain ongoing distribution and to provide security to staff working at CPN petrol stations.

\section{INSURANCE ATTACHMENTS}

The situation changed drastically on December 13, 1981, with the imposition of martial law. On that day, a ban on petrol trade was introduced [Obrady Komitetu Gospodarczego Rady Ministrów (The session of the Council of Ministers Economic Committee), 1981: 1, 2]. Therefore, under the rigorous conditions of martial law, actions were taken to significantly limit fuel sales. However, a complete ban on passenger car traffic (a solution suggested six months previously) was not implemented, though at the same time, drivers were forced to use up their fuel stocks. Six weeks before the martial law was introduced, the Ministry of Chemical and Light Industry had estimated that in some cases, individual stocks could be as large as 400 liters $^{4}$ [AAN, URM 135/37, p. 50]. This was partially evidenced by the sales figures - until September 1981, sales were 9\% higher than in the previous year. Probably, part of that excess was stored in barrels and fuel cans [AAN, URM 135/35, p. 103, 107].

Maintaining a complete ban on fuel trade was, of course, impossible. Gradually, special solutions were implemented. Fuel vouchers were to be

${ }^{4}$ In November 1981, guidelines were issued for mass media to stigmatize "hoarders". During one government session, Janusz Obodowski said: "[...] you were meant to get photo reporters to show this dirty business". 
provided, according to a strict hierarchy of recipients. The order was as following: armed forces, snow removal services, emergency services (medical, sanitary, veterinary, insemination), dairy co-operatives, food transport, banks, the National Insurance Company and the Social Insurance Institution, local public transport, military industries, technical services, PKS (State Motor Transport) motor transport company, forest transports [AAN, GIGE 7/19, p. 11-12]. On December 23, 1981, in seven largest Polish cities and in the Katowice and Warsaw regions, regulations were introduced concerning fuel purchases by private taxi drivers. They were authorized to buy a full tank of fuel every three days [AAN, GIGE 7/20, p. 21].

There were also two other groups who could purchase petrol more easily thanks to the introduction of martial law. The Council of Ministers Economic Committee gave this privilege to the disabled and to journalists working for the government media [AAN, GIGE 7/20, p. 25]. In Warsaw, there was a special petrol station only serving people working in national institutions and organizations. Fuel was sold there upon the demonstration of a special permission (permanent or single-use) [AAN, GIGE $7 / 20$, p. 30-31]. Only foreigners could buy fuel with no limitations (both those whose cars were registered in Poland and those who paid with dol-

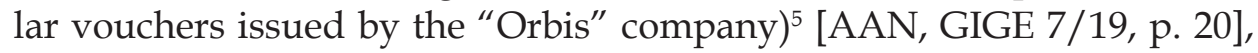
[GAP (Police Main Archive), 748/28 vol. 1, p. 220-221].

Therefore, the group most affected by the martial law restrictions were individual customers [AAN, URM 32/39, p. 8]. In January 1982, individual customers were sold $69 \%$ less petrol than in the previous year [AAN, GIGE 7/20, p. 37].

This rigor could not last long. In February 1982, a new way for individual customers to fuel their cars was introduced. However, a special "key" applied, based on the registration plate number and the current date: cars with registration numbers ending with 1 could buy their allotted amount of petrol on the $1^{\text {st }}, 11^{\text {th }}$ and $21^{\text {st }}$ day of the month; cars with registration numbers ending with $2-$ on the $2^{\text {nd }}, 12^{\text {th }}$ and $22^{\text {nd }}$ day of the month and so on. On the $31^{\text {st }}$ day of each month, individual customers were not allowed

${ }^{5}$ In Poland in the 1980s, fuel trade for foreigners was organized according to the following rules. Fuel for cars registered in socialist countries (excluding Yugoslavia) could be bought with "Orbis" vouchers with a value of 100, 300 or 500 złoty (for petrol), and 200 and 600 złoty (for diesel fuel). In the case of diesel fuel, the Polish złoty could be also used, but this did not apply to cars registered in East Germany. Users of passenger cars registered in capitalist countries and in Yugoslavia purchased petrol with "Orbis" vouchers valued at 5, 10 and 20 liters (for petrol), and 5, 10, 20 and 40 liters (for diesel fuel). 
to buy fuel at all. However, the permission only applied to filling the car tank, and amounts were limited:

- 10 liters for a passenger car with engine capacity up to $1200 \mathrm{~cm}^{3}$

- 15 liters for a passenger car with engine capacity above $1200 \mathrm{~cm}^{3}$

- 20 liters for a truck with a load up to 2 tons

- 25 liters for a truck with a load above 2 tons

The introduction of drastic limitations for private customers was necessary due to the difficult fuel supply situation in the country. The sales plan for the year 1982 estimated deliveries to be smaller by $16.5 \%$ compared with the previous year. Even bigger cuts were expected in the case of private customers - here, the anticipated decrease was $27 \%$ compared to the previous year. The introduction of these restrictions allowed to limit sales according to the plan, and was successful - in the first four months of 1982 (i.e. after three months of petrol rationing), petrol sales were $20 \%$ smaller than in the previous year [AAN, GIGE 7/20, p. 37-38]. This meant that rationing was effective - though still not effective enough. It cannot be said, though, that the rationing system introduced in 1982 was optimal, on the contrary - the regulations only acted as a stopgap solution that clearly could not last in the long run.

This temporary system was further regulated on July 1, 1982, when the so-called "attachments" from the National Insurance Company (PZU) were introduced. These "attachments" were in fact the first form of regular petrol rationing cards, introduced in the whole country.

Based on the PZU data, there were 5.3 million cars in Poland, and 4.3 million of them were privately owned. Users of private cars were entitled to receive the "attachments" [Sprawozdanie z działalności Państwowego Zakładu Ubezpieczeń za 1982 rok (A report on the activity of the PZU company operation for the year 1982), 1983: 31-32]. Rationing included 78- and 94-octane petrol. The ration sizes from February 1982 were kept. Sale of diesel fuel was excluded from the rationing system ${ }^{6}$ [Grzeszak A., 1985:3-4].

In the "attachment" system, the purchase of petrol was confirmed on the attachment to the obligatory civil liability insurance document. Before the sale, a CPN employee had to confirm the transaction by stamping the current date in a spot indicating a single ration. Ration sizes were not specified in the form, as they were announced separately every quarter. Ad-

\footnotetext{
${ }^{6}$ In subsequent years, desperate drivers tried to replace engines in their cars with diesel engines, sometimes falling prey to various swindlers.
} 
ditionally, the salesperson had to make their own record of the transaction [Jak zlikwidować benzynowy "przeciek" (How to eliminate the petrol "leak"), 1982: 2]. The introduced system generated an enormous amount of red tape and caused slower service at petrol stations [AAN, URM 32/22, p. 16].

Based on the attachment, it was possible to purchase the assigned ration three times a month (according to the calendar-based key). In the summer of 1982, cars with registration plates from out of the region were permitted to refuel any number of times, but within the quarterly ration (this was of course noted down in the attachment) [AAN, GIGE 7/4, p. 40-41]. This was meant to make life easier for drivers on holidays [AAN, GIGE 7/4, p. 42].

It was no coincidence that the "attachment" rationing system was introduced in the $3^{\text {rd }}$ quarter of the year, as it was anticipated that this quarter would be the most difficult, considering the existing petrol shortages and increased demand during the summer holiday season. It passed the test, though, and therefore the authorities decided to slightly liberalize the rationing system. On October 1, 1982, the "fueling calendar" was suspended, though car owners were still allowed to buy a full tank of petrol only three times a month (the limits were not modified). The option to buy one's quarterly ration outside of the region of residence was also maintained [AAN, GIGE 7/20, p. 46]. This created a loophole which could be used against the authorities' intentions. If someone was not able to use their monthly ration in their region of residence, they could buy the "overdue" rations in the neighboring region. Therefore, as the end of the quarter approached, the trips started, with Warsaw drivers going to Mszczonów (40 km away from Warsaw, in the Skierniewice region), Wyszków (45 km, but already in the Ostrołęka region) or Kołbiel (32 km, Siedlce region) only to fill their tank [Benzyna z II kwartału tylko do czwartku (Petrol from the second quarter only until Thursday), 1983: 1, 2].

The ban on filling fuel cans remained in force for some time ${ }^{7}$ (with the Militia searching the trunks of cars during car checks) [AAN, GIGE 7/20, p. 32, 34]. There were two reasons for that. The first one was of course to limit sales. Petrol is in a way similar to sugar or alcohol - it is relatively easy to stock, can be stored for a very long time and used as "currency". But the problem of drivers buying petrol "for later" was not the only rea-

${ }^{7}$ Of course, there were several exceptions to this rule, but special permissions were required, which were hard to get. A driver who had a fuel can in the trunk was required to have a document describing the type of container, its volume, the authorized amount of petrol, journey route, and date. 
son for banning sale in fuel cans. In 1981, the distinctive smell of gasoline started to ooze from garages, sheds, houses and, what is even worse, basements of apartment houses [AAN, URM 135/26, p. 7]. This stored petrol started to become a real fire hazard, which the ban on filling fuel cans was meant to partially contain. Later on, customers were allowed to put the excess fuel from their rations (that did not fit in the car tank) in fuel cans.

In August 1982, rationing of the so-called "blue" petrol (78-octane) was suspended, and limited amounts could even be put in fuel cans [Od $d z i s$ etylina 78 nie reglamentowana (78-octane petrol no longer rationed), 1982: 1; AAN, GIGE 7/20, p. 43]. The reason was not the excess of this fuel, but rather the difficulties related to its storage [AAN, GIGE 7/20, p. 42]. This type of petrol became extremely popular, despite the fact that the only approx. $25 \%$ of the cars could run on it [Gutorski K., 1981: 21]. In some markets, it was possible to buy parts that enabled the engines of Fiats 126p to run on 78-octane petrol [Wolny rynek reaguje (The free market reacts), 1982:2]. According to press reports, with time, the situation returned to normal, and the demand for the "blue" petrol stabilized [Nie ma kłopotów $z$ nabyciem benzyny niebieskiej (No more trouble with purchasing the blue petrol), 1982:1, 2]. Rationing of blue petrol was reinstated in March 1983.

The system described above was created to satisfy the needs of regular private car users. For many Poles, though, a car was not just a private means of transport, but was also used for professional purposes. The provided rations could not fulfill the needs of these people even in the slightest. Therefore, there was a whole range of exceptions (which of course applied only to drivers buying fuel at petrol stations). On July 1, 1982 (i.e. on the day when the "attachment rationing" system entered into force), all centrally- and regionally-issued permissions for extra petrol purchases were annulled. Instead, a single system of permissions was introduced:

- national permissions - valid in the whole country until the date set by the issuer;

- regional permissions - valid in the region where they were issued until the date set by the issuer;

- singe-use permissions - valid in the whole country until the date set by the issuer, for a single purchase of a full tank of fuel;

- special permissions - valid in the region where they were issued until the date set by the issuer, allowed the holder to fill a fuel can (solution introduced for users of machines with combustion engines)

- "Taxi" permissions - valid only in the city where the taxi was registered (such regulations had already been introduced) [AAN, GIGE 7/4, p. 1-4]. 
Truck owners with permanent permissions could buy 30 liters (for trucks with a load up to 2 tons) or 40 liters (for trucks with a load above 2 tons) three times a month. Private taxi drivers could buy fuel once every three days, with a maximum of 45 liters, and only to fill the car tank [AAN, GIGE 7/20, p. 40]. Also, foreigners with cars registered in Poland had special permissions to buy petrol ${ }^{8}$ [Zarzadzenie Ministra Komunikacji $z$ dnia 15 marca 1976 r. w sprawie oznaczania pojazdów samochodowych i przyczep (The decision of the Minister of Transport of March 15, 1976 on labeling cars and trailers)].

The problem of additional fuel ration size (exceeding the norms discussed above) was solved in a rather interesting way. The volume of the car's fuel tank was used as the unit of measurement. In order to decrease rations (and avoid situations in which the capacity of the tank was artificially increased), top limits were also determined. A list of car makes and models was made (comprising 100 positions), along with the assigned maximum fuel amount. For passenger cars, the limit was typically five liters less than the capacity indicated by the manufacturer. Special exceptions were made e.g. in the case of Fiat 126 p, owners could buy 20 liters of petrol, while the nominal capacity was 21 liters. Mercedes owners, on the other hand, were treated quite harshly - their rations were smaller by 10-12 liters than the nominal capacity, which to be fair, was quite big anyway [AAN, GIGE 7/4, p. 14-16]. For trucks, differences were much larger - from 15 liters in the case of Nysa and Żuk, to 60 in the case of Jelcz [AAN, GIGE 7/4, p. 14-16]. This meant that petrol rations were practically determined by the make of a car.

Of course, the limits of additional permissions for regions were strict, and significantly differed from those required. In 1983, during his visit in Przemyśl, deputy prime minister Zbigniew Szałajda was surprised to find out that this region received only $38 \%$ of the required ration. After his personal intervention, this was increased to 50\% [AAN, GIGE 7/19, p. 85-86.].

The system described above only applied to the non-nationalized sector, which consumed around $50 \%$ of liquid fuels. The remainder was consumed by the nationalized sector, which was also subjected to strict regulation of fuel sale. Most of the fuel was distributed in garaged petrol

${ }^{8}$ Such cars had green registration plates with white characters. The first letter of the number was always "I", followed by the symbol of the region. This is how foreigners and foreign legal persons in Poland registered their vehicles (this did not include diplomats and, later on, also people with permanent residency cards). 
stations. In the case of purchases made in public petrol stations, the customers were required to have petrol tickets.

The year 1983 was particularly difficult in terms of fuel supply. It was estimated that there would be $6 \%$ less petrol than in the previous year, although the number of cars increased by around 200,000. This meant that in five years, petrol supply decreased by $9 \%$, while the number of cars increased by 59\% [AAN, URM 1.4/35, p. 43]. As of October 1, 1983, drivers could use only seven coupons per quarter. This meant that they lost two of their fuel rations for the period. Similar limitations were expected in the first quarter of the year 1984 [Mimo najazdu klientów, sprawna sprzedaż paliw w CPN (Despite the crowds, sale of fuels at CPNs goes smoothly), 1983: 1,2; Mniej benzyny jesienia $i$ zima (Less petrol in the autumn and winter), 1983: 2; AAN, URM 1.4/35, p. 45]. Similar limitations were also introduced for nationalized economic entities [AAN, URM 32/84, p. 96].

Limitations also affected the system of additional permissions. In mid1983, the rules were modified, in particular with regard to the specific amounts [AAN, GIGE 7/19, p. 55, 60; AAN, GIGE 7/19, p. 46-47]. New document formats were also introduced for the five permission types (three of them allowed variants):

- permission to purchase $2 \times 30$ or $4 \times 30$ liters of petrol in one month valid nationally until the date set by the issuer

- permission to purchase $2 \times 15$ or $4 \times 15$ liters of petrol in one month valid nationally until the date set by the issuer

- permission to make a single purchase of 5 or 15 liters of petrol - valid nationally until the date set by the issuer

- permission to buy 5 or 20 liters of fuel into fuel cans ${ }^{9}$ - valid nationally until the date set by the issuer

- permission to buy petrol for taxis, valid until the time indicated on the permission and only in the indicated city (ration assigned separately) [AAN, GIGE 1/2, p. 101].

In order to simplify the identification of these people, a list of 17 categories of "private car owners who can be granted permissions to buy extra amounts of petrol" was prepared. Among the privileged groups were e.g. members of the parliament, doctors, veterinarians and inseminators, postmen, the disabled, taxi drivers, officers of the Polish People's Army and

9 “[...] technically for stationary combustion engines and non-stationary devices with combustion engines (including power generating units, engine boats, mowers, saws, etc.)" [AAN, GIGE 1/2, p. 101]. 
Ministry of Home Affairs, and "others who made particular contributions to the welfare of the Polish People's Republic and the region, appointed by the head of regional administration" [AAN, GIGE 1/2, p. 104-105]. Foreigners with "green" number plates were assigned identical rations as Polish citizens. However, they were allowed to additionally purchase "Orbis" fuel vouchers with foreign currencies [AAN, GIGE 1/3, p. 113114]. Of course, regulations allowing for additional purchase of petrol partially alleviated the consequences of the rather small regular rations [AAN, URM 214/20, p. 5].

These solutions were accompanied by other similar actions in the nationalized sector and intensified fight against the black market.

\section{PETROL CARDS}

The forms of rationed sale to consumers described above and introduced on July 1, 1982 did not work out in practice. Therefore, at the same time, the authorities thought about introducing traditional rationing cards for petrol. The CPN company ordered their print as early as April 1982. The system was ready in July 1982, and the Economic Committee of the Council of Ministers started the debate over it. The system was to enter into force on October 1, 1982 [AAN, URM 32/22, p. 17], however, both the Chemical and Light Industry Ministry and the Main Inspectorate of Energy Management were against it. It was emphasized that the system introduced at the beginning of July worked well and no modifications were needed [AAN, GIGE 7/20, p. 42]. This was not true - the system had to be improved. There were more and more counterfeits of the "attachments" and reported cases of extortion. The lack of strict control in the "attachment" system was the direct reason for introducing traditional rationing cards for petrol. The authorities could not cope with the fact that petrol station staff constantly broke the rules, either by not stamping the documents to confirm the purchase or by making stamps that were easily removed. It was decided that the introduction of traditional cards with coupons that have to be cut would end the problem. The crash in petrol supplies in 1983 reinforced the need to implement the solution.

In the autumn of 1983, work on a new rationing system was resumed, with a view to "streamlining and tightening the rationing system for engine fuels" [AAN, GIGE 7/19, p. 142]. This resulted with the introduction 
of a "mature" system of petrol rationing on March 1, 1984, which remained in force for the four subsequent years [Wycinanie kuponów zamiast stemplowania (Cutting coupons instead of stamping), 1984: 2]. As stipulated in the first sentence of the Council of Ministers decree, this decision was adopted "in order to adapt the consumption of engine fuels to the level of supply [...] [Uchwała nr 27 Rady Ministrów z dnia 20 lutego 1984 r. w sprawie sprzedaży benzyn silnikowych odbiorcom prywatnym oraz jednostkom gospodarki nie uspotecznionej (The decree no. 27 of the Council of Ministers of February 20, 1984 on the sale of petrol to individual owners and non-nationalized economic entities)]. Petrol rationing cards were used in this form until the end of 1988, when the rationing system for fuel was discontinued.

\section{CONCLUSIONS}

The rationing system for fuel was introduced in the Polish People's Republic in a chaotic manner. The authorities were not prepared to launch such a regulatory mechanism. Therefore, it took exactly three years from the moment the concept of a mature rationing system for petrol first appeared to the introduction of rationing cards. During this time, two groups clashed: the proponents of the card system and the opponents. This conflict, and the lack of decisive actions, prolonged the preparation of the final form of the fuel sale rationing system. This intensified the chaos and market insecurity, perpetuated negative behaviors (e.g. speculation), and undermined trust towards national regulations.

The history of rationed fuel sale in the Polish People's Republic is an excellent example of how crucial it is for the state to have rationing sale systems ready at all times. The quick launch of the system in a time of market imbalance can help prevent a larger crisis. Indirectly, a quick reaction can also affect the level of trust towards the authorities.

\section{BIBLIOGRAPHY}

\section{Archive materials}

The Archive of New Files, units: Main Inspectorate of Energy Management, Institute of Internal market, the Council of Ministers Archive of the Institute of National Remembrance Police Main Archive 


\section{Printed resources}

Sprawozdanie z działalności Państwowego Zakładu Ubezpieczeń za 1982 rok [A report on the activity of the PZU company operation for the year 1982] (1983), PZU, Warsaw, pp. 3132.

Uchwała nr 27 Rady Ministrów z dnia 20 lutego 1984 r. w sprawie sprzedaży benzyn silnikowych odbiorcom prywatnym oraz jednostkom gospodarki nie uspołecznionej [The decree no. 27 of the Council of Ministers of February 20, 1984 on the sale of petrol to individual owners and non-nationalized economic entities], (1984), Monitor Polski, no. 5, item 42.

Zarządzenie Ministra Komunikacji z dnia 15 marca 1976 r. w sprawie oznaczania pojazdów samochodowych i przyczep [The decision of the Minister of Transport of March 15, 1976 on labeling cars and trailers], (1976), Monitor Polski, no. 14, item 67.

\section{Literature}

Grzeszak A. (1985), Kłopoty to ich specjalność [Trouble is their area of expertise], Motor, no. 19, pp. 3-4.

Gutorski K., Czym zastapić benzynę? [If not petrol, then what?] (1981), Motoryzacja, no. 1, p. 21.

Jak zlikwidować benzynowy "przeciek" [How to deal with the petrol "leak”] (1982), Trybuna Ludu, no. 174, p. 2.

Kornai J. (1985), Niedobór w gospodarce, [Economics of shortage], PWE, Warsaw.

Mała Encyklopedia ekonomiczna [Short economic encyclopedia], (1974), PWE, Warsaw.

Mimo najazdu klientów, sprawna sprzedaż paliw w CPN [Despite the crowds, sale of fuels at CPNs goes smoothly] (1983), Życie Warszawy, no. 234, p. 1-2.

Mniej benzyny jesienia i zima [Less petrol in the autumn and winter] (1983), Motor, no. 42, p. 2.

Nie ma kłopotów z nabyciem benzyny niebieskiej [No more trouble with purchasing the blue petrol] (1982), Życie Warszawy, no. 201, p. 1-2.

Obrady Komitetu Gospodarczego Rady Ministrów [The session of the Council of Ministers Economic Committee], (1981), Trybuna Ludu, no. 297, p. 1- 2.

Od dziś etylina 78 nie reglamentowana [78-octane petrol no longer rationed], (1982), Życie Warszawy, no. 186, p. 1

Rozsadku! [Think!], (1981), Motor, no. 29, p. 2.

Suchecki B. (1981), Po benzynowej pustyni, [In the petrol desert], Motor, no. 32, p. 5; AAN, URM 32/5, f. 14.

Szlichciński K. (2002), Brytyjska gospodarka wojenna 1939-1945 [War economy in Britain in the years 1939-1945], Bellona, Warsaw.

Wolny rynek reaguje [The free market reacts], (1982), Motor, no. 26, p. 2.

Wycinanie kuponów zamiast stemplowania [Cutting coupons instead of stamping], (1984), Życie Warszawy, no. 50, p. 2.

Andrzej Zawistowski, PhD, works at the Warsaw School of Economics Economic and Social History Department. His main interests include Poland's modern history, with special focus on economic and social aspects. His most recently published book is: Bilety do sklepu. Handel Reglamentowany w PRL [Tickets to shops. Rationed trade in the Polish People's Republic], PWN, Warsaw, 2017. 